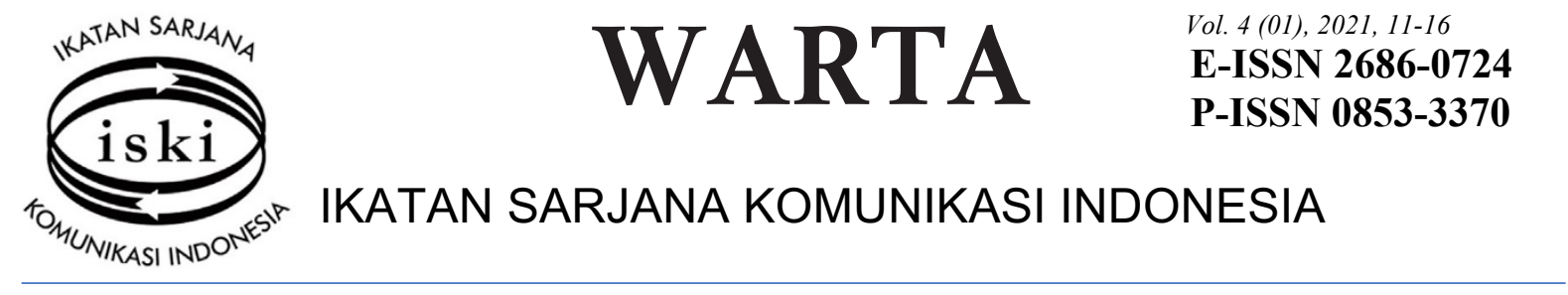

\title{
Implementasi Komunikasi Persuasif Menjadi Barista
}

\author{
http://dx.doi.org/10.25008/wartaiski.v4i1.77 \\ Geivindra G.R. Hadiputra ${ }^{1}$, Deddy Muharman ${ }^{2}$ \\ ${ }^{1,2}$ Institut Komunikasi dan Bisnis LSPR \\ J1. KH Mas Mansyur Kav. 35, Jakarta 10220, Indonesia \\ "e-mail korespondensi: deddy.m@1spr.edu
}

Submitted: 20/02/2021, Revised: 26/05/2021, Accepted: 10/06/2021

Accredited by Kemristekdikti No. 30/E/KPT/2019

\begin{abstract}
Fulcaff coffee shop a role model for learning coffee. especially in the city of Depok. This research was conducted to determine the persuasive communication techniques used by mentors in the coffee course conducted at the Fulcaff Barista Course. Researchers used descriptive qualitative methods with interviews and observations. The data is supplemented with secondary data from previous research, archives, and news related to the research topic. In this study, researchers focused on how mentors use persuasive techniques in accordance with Effendy's theory of persuasive communication techniques. During the course the mentor uses association techniques, integration techniques, structuring techniques and reward techniques. The results showed that mentors were more dominant in using integration techniques to create a good learning atmosphere so that participants could receive maximum information. Appropriate use of persuasive communication techniques is also able to maintain interest in learning from course participants.
\end{abstract}

Keywords: Communication, persuasive techniques, coffee course, learning interest

\begin{abstract}
Abstrak
Kedai kopi Fulcaff menjadi salah satu panutan untuk belajar menjadi barista khususnya di kota Depok. Penelitian ini dilakukan untuk mengetahui teknik komunikasi persuasif yang digunakan oleh mentor dalam menyampaikan materi pembelajaran di kursus barista Fulcaff agar mudah dipahami oleh peserta kursus. Peneliti menggunakan metode penelitian kualitatif deskriptif dengan pengumpulan data melalui wawancara dan observasi. Data sekunder dari penelitian sebelumnya, arsip, serta berita terkait dengan topik penelitian. Dalam penelitian ini peneliti memfokuskan bagaimana mentor menggunakan teknik persuasif sesuai dengan teori teknik komunikasi persuasif. Selama kursus berlangsung mentor menggunakan teknik asosiasi, teknik integrasi, teknik tataan dan juga teknik ganjaran. Hasil penelitian menunjukan mentor lebih dominan menggunakan teknik integrasi untuk menciptakan suasana belajar yang baik agar penerimaan informasi peserta bisa maksimal. Penggunaan teknik komunikasi persuasif secara tepat juga mampu menjaga minat belajar dari peserta kursus.

Kata Kunci: Komunikasi, teknik komunikasi persuasif, kursus kopi, minat belajar
\end{abstract}

\section{PENDAHULUAN}

Indonesia menempati posisi keempat dalam negara negara produsen dan eksportir kopi terbesar di dunia (Szenthe, 2019). Saat ini kegiatan minum kopi sudah bukan lagi tuntutan selera semata namun menjadi gaya hidup masyarakat perkotaan dan menjadi gaya hidup sebagian anak muda yang berorientasi pada nilai kebendaan maupun prestise (Herlyana, 2014). Itu sebabnya kedai kopi dengan pekerja anak-anak muda milenial tumbuh bagaikan cendawan di musim hujan di sebagai kota-kota besar Indonesia.

Tanaman Kopi masuk ke Nusantara pada masa kolonial Belanda, dan membuat Indonesia menjadi salah satu negara penghasil kopi utama di dunia hingga kini (Gumulya \& Helmi, 2017). Saat ini tren 
minum kopi merebak di kalangan masyarakat terutama kaum muda, bahkan hingga ke kota-kota kecil. Bahkan menurut International Coffe Organization (ICO), konsumsi kopi di Indonesia mencapai 4,6 juta sehingga menempatkan Indonesia sebagai peringkat enam dunia dalam hal konsumsi kopi.

Tidak sedikit masyarakat yang menganggap meminum kopi sebagai hobi. Mereka tidak hanya menyukai kopi namun juga tertarik belajar meracik kopi, sehingga memunculkan kegiatan kursus menjadi barista. Banyaknya variabel dalam meracik kopi serta materi kursus yang kompleks, menjadi tantangan bagi mentor dan peserta kursus. Oleh karena itu diperlukan mentor berpengalaman, bersertifikasi, kredibel dan memiliki kemampuan berkomunikasi yang baik. Kemampuan melakukan persuasi untuk mencapai tujuan dari pengirim pesanmutlak diperlukan oleh mentor peracik kopi agar kegiatan kursus berjalan efektif (Dainton \& Zelley, 2017).

Komunikasi persuasif mampu membantu peserta dalam memahami materi kursus dan menjaga minat belajar peserta. Bagaimana teknik komunikasi persuasif yang tepat dan dapat membantu mentor dalam menyampaikan materi yang rumit bagi peserta menjadi topik bahasan studi ini. Adapun tujuan penelitian ini adalah untuk mengetahui teknik komunikasi persuasif yang dilakukan oleh mentor kursus kopi di Barista Fulcaff. Hasil dari penelitian ini diharapkan dapat menambah wawasan bagi publik untuk dalam menerapkan komunikasi persuasif pada kursus kopi, selain menjadi sumber informasi dan referensi bagi kedai kopi yang menawarkan workshop.

\section{KERANGKA TEORI}

Komunikasi persuasif diartikan sebagai suatu proses untuk mempengaruhi pendapat, sikap dan tindakan orang dengan menggunakan manipulasi psikologis sehingga orang tersebut bertindak seperti atas kehendaknya sendiri (Rakhmat, 2008). Perloff menyampaikan "persuasion is the study of attitudes and how to change them" (2017). Persuasi adalah studi tentang sifat dan cara mengubahnya. Persuasif didefinisikan sebagai proses simbolik dengan komunikator mencoba meyakinkan orang lain untuk mengubah sikap atau perilaku mereka melalui transmisi pesan, dalam suasana pilihan yang bebas (Perloff, 2017).

Tujuan komunikasi persuasif adalah untuk mempengaruhi sikap, pendapat, dan perilaku audiens atau khalayak (Soemirat \& Suryana, 2014). Dari beberapa pengertian tersebut, maka dapat disimpulkan komunikasi persuasif adalah usaha untuk menyampaikan sebuah pesan yang dilakukan tanpa paksaan untuk memperoleh respon dari khalayak. Respon yang dimaksut disini adalah mendorong, mengajak dan mengubah perilaku ataupun pola pikir khalayak.

Adapun unsur-unsur dalam suatu proses komunikasi persuasif menurut Soemirat dan Suryana (2014) adalah Persuader, persuadee, persepsi, pesan persuasif, saluran persuasif, umpan balik dan efek. Littlejohn, Foss \& Oetzel (2017) menyatakan, persuasi dipandang sebagai cara terbaik untuk mencoba membuat perubahan. Komunikator dapat menggunakan persuasi untuk mengatasi audiensi yang mampu menghasilkan perubahan. Komunikasi persuasif menjadi konsep utama dalam penelitian ini. Untuk menjaga minat belajar peserta kursus kopi diperlukan mentor yang memiliki kemampuan berkomunikasi yang baik dan memiliki kapabilitas untuk mengajarkan materi pada kursus.

Mentor harus memiliki kemampuan komunikasi persuasif yang baik agar dapat membujuk, meyakinkan dan menarik peserta kursus, karena materi yang diberikan cukup rumit dan saling berkaitan, ditambah dengan istilah yang sulit dipahami oleh orang awam. Oleh karena itu penting adanya komunikasi persuasif dalam penyampain materi dalam kursus kopi. Adanya perubahan pola pikir ke arah yang lebih baik dapat dijadikan acuan kesuksesan sebuah komunikasi persuasif.

Effendy (2008) menyebutkan lima teknik yang digunakan dalam komunikasi persuasif: (1) Teknik Asosiasi, yakni penyajian pesan persuasif dengan cara menumpangkannya pada suatu objek atau sebuah peristiwa; (2) Teknik Integrasi, dalam teknik ini komunikator berusaha menyatukan diri secara komunikatif dengan komunikan. Contohnya penggunaan kata "kita" bukan "saya" atau "kami". "Kita" berarti "saya dan anda"; (3) Teknik Tataan, merupakan seni menata pesan dengan imbauan emosional sedemikian rupa sehingga komunikan menjadi tertarik perhatiannya. Penataan pesan yang ingin disampaikan harus dilakukan menarik dan disusun agar komunikan tertarik, namun tidak mengubah fakta dalam pesan tersebut; (4) Teknik Ganjaran yakni, mempengaruhi orang lain dengan cara mengiming-iming hal yang menguntungkan atau menjanjikan harapan. Teknik ini sering dipertentangkan dengan teknik pembangkitan rasa takut atau fear arousing, yakni suatu cara yang bersifat menakut-nakuti; (5) Teknik Red-herring, seni seorang komunikator untuk memenangkan perdebatan dengan mengenakan argumentasi yang lemah untuk kemudian mengalihkannya ke aspek 
yang dikuasai oleh komunikator. Teknik-teknik tersebut dapat digunakan oleh komunikator ketika menghadapi komunikan agar komunikasi persuasif dapat berhasil, sesuai dengan harapan komunikator dan tentunya berjalan efektif sesuai dengan tujuan kursus.

Minat adalah kesenangan atau perhatian yang terus menerus terhadap suatu obyek karena adanya pengharapan akan memperoleh manfaat (Yusuf, 2010). Menurut Slameto (2010), minat adalah suatu rasa suka dan rasa ketertarikan terhadap suatu hal atau aktivitas yang dilakukan secara inisiatif tanpa ada yang mendesak untuk melakukannya. Menurut Djamarah (2008), minat adalah kecenderungan yang menetap untuk memperhatikan dan mengenang beberapa aktivitas. Seseorang yang berminat terhadap aktivitas akan memperhatikan aktivitas itu secara konsisten dengan rasa senang.

Slameto (2010) mengungkapkan, belajar merupakan sebuah proses atau usaha yang dilakukan seseorang untuk memperoleh suatu pengetahuan atau tingkah laku yang belum diketahui sebelumnya, sebagai salah satu hasil dari pengalamannya sendiri dalam berinteraksi dengan lingkungan sekitarnya. Menurut Suyono (2011), belajar adalah suatu aktivitas untuk memperoleh pengetahuan, meningkatkan keterampilan, memperbaiki perilaku, sikap dan memperkokoh kepribadian.

Dari beberapa pernyataan tersebut bisa disimpulkan, seseorang yang memiliki minat tertentu akan terus menaruh perhatian kepada aktivitas itu secara konsisten dengan rasa senang. Dalam sebuah kursus diperlukan minat agar peserta benar-benar menyadari pentingnya kursus tersebut. Belajar merupakan proses perubahan yang bersifat permanen secara disengaja untuk mengetahui sesuatu yang baik. Minat dan belajar memiliki hubungan yang erat. Minat dalam belajar dapat membawa efek yang baik, seperti yang sudah dijelaskan sebelumnya, rasa ketertarikan tanpa paksaan oleh pihak lain, sehibgga belajar akan terasa senang dan tidak membosankan.

Minat belajar para peserta kursus harus dipertahankan oleh mentor, agar peserta tetap bersemangat dalam mengikuti kursus maupun setelah kursus berlangsung. Menurut Slameto (2010) ada beberapa indikator bahwa seseorang berminat belajar yakni: (1) Perasaan senang. Apabila seorang siswa atau seseorang memiliki perasaan senang terhadap pelajaran tertentu maka tidak akan ada rasa terpaksa untuk belajar; (2) Keterlibatan Siswa, yakni ketertarikan seseorang terhadap obyek yang mengakibatkan orang tersebut senang untuk melakukan atau mengerjakan kegiatan tersebut; (3) Ketertarikan, merupakan segala yang berhubungan dengan daya dorong siswa terhadap ketertarikan pada sesuatu benda, orang, kegiatan atau bisa berupa pengalaman afektif yang dirangsang oleh kegiatan itu sendiri; (4) Perhatian Siswa, merupakan konsentrasi siswa terhadap pengamatan dan pengertian dengan mengesampingkan yang lain.

\section{METODE PENELITIAN}

Penelitian ini menggunakan pendekatan kualitatif. Data diperoleh melalui teknik wawancara dan observasi dan berbagai dokumentasi menyeluruh (Mukhtar, 2013). Sebelum melakukan wawancara, terlebih dahulu dilakukan purposive sampling untuk memilih narasumber yang tepat dengan pertimbangan tertentu pada observasi agar narasumber benar-benar mewakili.

Informan yang dipilih antara lain: Informan 1 yakni pemilik sekaligus mentor kursus Barista Fulcaff; Informan 2, seorang Asisten mentor kursus Barista Fulcaff; Informan 3, seorang peserta kursus Barista Fulcaff yang dikategorikan sangat aktif; Infornab 4, peserta kursus Barista Fulcaff yang dikategorikan aktif; dan Informan 5, peserta kursus Barista Fulcaff yang dikategorikan kurang aktif.

Untuk menganalisis data, peneliti menggunakan teknik analisis data dari Miles dan Huberman yaitu Reduksi Data, Display Data, Verifikasi dan Kesimpulan. Adapun fokus penelitian adalah teknik komunikasi persuasif oleh Effendy. Untuk trianggulasi digunakan trianggulasi sumber dalam mengecek data hasil wawancara dan data hasil observasi.

\section{HASIL PENELITIAN}

Mentor kursus mencoba menarik perhatian peserta dengan menyederhanakan penyampaian materi sehingga materi itu mudah dimengerti. Ini sesuai dengan yang disampaikan oleh informan 1 yang bertugas sebagai mentor. Ia mengatakan memulai kursus dengan hal yang sederhana dan mengenalkan berbagai istilah. Pasalnya, banyak peserta belum paham istilah kopi seperti fragrances, balance, aroma, after taste. Informan 1, saat mengajarkan hal-hal baru selalu menggunakan analogi tertentu yang mudah dipahami peserta kursus.

Informan 2 yang bertugas membantu mentor saat kursus berlangsung, menilai bahwa komunikasi oleh informan 1 sangat baik. Untuk penggunaan analogi memang tidak dapat digunakan terlalu sering, 
hanya yang cocok saja. Menurut observasi, mentor menggunakan analogi saat menjelaskan, after taste. Layaknya seperti saat kita memakan buah durian, rasa yang tertinggal lebih awet bandingkan ketika memakan buah apel. Kenangan dan kesan yang muncul akan berbeda.

Informan 3 merupakan peserta yang dikatogorikan sangat aktif. Dia mengingat mentor menjelaskan tentang after taste dalam kopi. Dia mengibaratkan after taste itu seperti memakan durian dan apel. "Kalau makan durian kan rasanya ngebekas di mulut lebih lama. Kalau apel sebentar aja ringan rasanya," katanya.

Informan 4 merupakan peserta yang dikategorikan aktif. Dia berkomentar, mentor menjelaskan aftertaste itu juga seperti memakan durian, sama seperti yang disampaikan Informan 3. "Itu bagus, dia ngambil contoh terdekat," katanya. Informan 5, merupakan peserta yang dikategorikan sebagai peserta yang kurang aktif. Dia berpendapat, penggunaan analogi membantunya dalam kursus dan materi menjadi lebih mudah dipahami.

Mentor menggunakan analogi sebanyak dua kali dalam kursus selama satu hari yang berlangsung lima jam, terbagi atas tiga jam teori dan dua jam praktik. Mentor terlihat menumpangkan pesan materi kursus. Mentor memilih peristiwa atau objek yang dekat dengan peserta. Dalam penggunaannya, teknik asosiasi yang dilakukan di kursus Fulcaff sudah menjadi hal yang biasa. Dengan penggunaan analogi yang relevan dengan materi, mentor dapat menarik perhatian dan membantu pemahaman peserta

\section{Teknik Integrasi}

Penggunaan teknik integrasi dilihat dari kemampuan mentor untuk menyatukan diri dengan peserta kursus. Menurut Effendy, integrasi adalah kemampuan komunikator untuk menyatukan diri secara komunikatif dengan komunikan. Di kursus barista Fulcaff, mentor selalu menggunakan kata "kita" bukan kata "kami". Selain itu mentor mencoba membaur dengan obrolan sebelum mulai kursus. Mentor mencoba mengenal peserta satu per satu dengan berbincang dengan mereka. Dengan begitu tercipta rasa kesatuan sekaligus menciptakan rasa nyaman selama kursus.

Kursus menjadi barista merupakan kursus yang bersifat informal. Informan 1 mengatakan meskipun dia seorang mentor yang memiliki sertifikasi dan pengalaman tinggi, namun dia harus masuk ke dunia peserta menggunakan bahasa yang mudah diterima. Bahasa kebersamaan, kekompakan dan kebersamaan salah satunya adalah menggunakan diksi "kita" untuk memahami psikologis dan mencairkan suasana.

Informan 2 mendukung pernyataan Informan 1 dengan mengatakan penggunaan diksi "kita" merupakan pilihan yang paling cocok. Ia juga menambahkan, hal itu berdampak baik bagi peserta, karena mereka kelihatan lebih enjoy dan suasana menjadi lebih rileks, sehingga suasananya seperti sedang tidak belajar.

Untuk melihat bagaimana teknik ini berdampak, peneliti menggali informasi terkait teknik ini kepada peserta kursus. Informan 3 menjelaskan, ketika kursus berlangsung ia merasa dihargai, dan suasana di dalam kursus juga nyaman sehingga ia merasa dekat dengan mentor. Informan 4 berkata, ketika awal kursus ia menyadari bahwa mentor mencoba menghilangkan gap dan menghargai pendapat peserta.

Sementara itu Informan 5 mengatakan, ia diperlakukan setara dengan peserta lain, walaupun sebetulnya ia merasa minder karena belum mengerti banyak materi kursus. Saat kursus berlangsung, mentor mengajak dia berdiskusi tentang materi kursus yang kemudian ketika berdiskusi, mentor tetap mendengarkan pendapatnya.

Hasil observasi yang dilakukan tercatat 50 kali mentor menggunakan kata "kita" selama kursus berlangsung. Teknik integrasi bertujuan untuk menciptakan hubungan antara komunikator dan komunikan. Ketika sudah ada rasa nyaman, maka hilanglah gap antara mentor dan peserta sehingga proses pembelajaran dan diskusi bisa lebih maksimal. Batasan untuk beragumen dalam kursus pun akan sedikit demi sedikit berkurang. Hubungannya dengan minat belajar, ketika mentor berhasil menyatukan diri maka akan timbul perasaan senang, perasaan nyaman dan suasana dari peserta kursus yang mendukung aktivitas belajar. Ketika mentor berhasil menyatukan diri maka timbul perasaan senang dan nyaman dari peserta kursus yang mendukung aktivitas belajar.

\section{Teknik Tataan}

Dalam teknik tataan dijelaskan bahwa penataan pesan yang ingin disampaikan kepada komunikan harus dilakukan secara menarik dan disusun sedemikian rupa agar komunikan tertarik atau memiliki 
kecenderungan untuk mengikuti isi pesan tersebut (Effendy, 2008). Informan 1 menggunakan teknik ini pada saat menyusun materi kursus. Materi dibuat sedemikian rupa sehingga menarik perhatian peserta kursus. Penataan pesan yang menarik, mudah diingat, enak didengar dan menjadi salah satu acuan dalam teknik ini, sehingga dapat membantu peserta untuk memahami materi yang diberikan oleh mentor. Mentor menggunakan teknik ini dengan memperhatikan kesesuaian materi yang diberikan. Mentor tidak mengurangi fakta atau merubah fakta dalam materi tersebut.

Mentor menyampaikan pesan dengan bahasa yang nyeleneh sehingga menarik perhatian peserta. Mentor juga menyampaikan materinya, terkadang menggunakan kata yang berakhiran sama supaya enak didengar. Selain itu mentor juga menyederhanakan beberapa materi supaya mudah diingat dan dimengerti oleh peserta kursus. Menurut informan 2, kalau pesan sudah ditata dengan baik, peserta lebih memperhatikan materi kursus sehingga materi itu membekas di otak mereka.

Informan 4 mengatakan, materi lebih mudah diingat saat mempelajari materi kursus kopi secara mendalam. Menurutnya pesan yang terlalu panjang dan tidak menarik membuatnya bosan. Sementara itu Informan 5 menyatakan, materi yang disampaikan mentor menurutnya menarik dan tidak membosankan. Ia mementingkan penyampaian mentor yang menarik pada saat kursus.

Berdasarkan observasi yang dilakukan, mentor menggunakan teknik tataan sebanyak lima kali. Hubungan teknik ini dengan minat belajar peserta dapat dilihat ketika penggunaan teknik ini dapat menarik perhatian peserta. Peserta kursus tertarik kepada materi yang disampaikan komunikator yang dalam hal ini adalah mentor.

\section{Teknik Ganjaran}

Mentor melakukan teknik ini dengan mengiming-imingi peserta dengan hadiah berupa minuman gratis yang akan diberikan setelah kursus selesai dilakukan. Tak jarang juga mentor memberikan pujian secara langsung terhadap peserta kursus apabila mereka melebihi ekspektasi sendiri. Adanya imingiming hadiah bila berhasil melakukan sesuatu yang diminta membuat peserta menjadi semakin bersungguh-sungguh belajar. Menurut informan 1, teknik itu dilakukan agar peserta termotivasi belajar sekaligus untuk mencairkan suasana.

Menurut hasil observasi, mentor menggunakan teknik ini sebanyak dua kali, pada saat memancing peserta untuk bertanya dengan iming-iming diberi kopi hasil seduhan sang mentor. Kedua, saat pelaksanaan praktik, mereka diiming-imingi kopi gratis dengan seduhan terbaik. Hal itu disambut baik oleh seluruh peserta kursus.

Pada kesempatan lain, peneliti melihat peserta jauh lebih semangat dan termotivasi untuk meyeduh kopi setelah mentor berjanji memberikan es kopi susu gratis bagi kelompok yang menang. Peserta lebih aktif berdiskusi dengan anggota kelompoknya agar menang kompetisi. Menurut informan 3, ia merasa terdorong dan harus berfikir keras untuk menyelesaikan tugas sesuai arahan mentor. Dengan imingiming, ia termotivasi untuk berlomba jadi pemenang.

Hal serupa disampaikan informan 4. Ia menjadi semangat dan termotivasi melakukan yang terbaik. Cara ini menurutnya berhasil membuatnya menjadi lebih antusias. Dalam pelaksanaannya hampir seluruh peserta aktif dalam setiap aktivitas yang diberikan karena penggunaan teknik ganjaran. Teknik ini bisa membantu mempertahankan minat belajar dan menambah minat peserta untuk semakin terpacu untuk mempelajari kopi dengan lebih maksimal.

Selain itu mentor menggunakan teknik ini untuk memancing pertanyaan dan memotivasi peserta untuk menyelesaikan tugas yang diberikan. Peserta merasa terdorong, jauh lebih semangat untuk melakukan yang terbaik saat praktik.

\section{Teknik Red-Herring}

Teknik ini sering digunakan pada saat komunikator berada dalam posisi terdesak. Dalam pelaksanaandi kursus kopi Fulcaff, mentor tidak terlihat terdesak, sehingga tidak menggunakan teknik ini. Menurut hasil wawancara dengan informan terkait penggubaan teknik ini sebagai berikut: Informan 1, menjelaskan ia berusaha 100 persen menjawab pertanyaan dari peserta. Informan 2, menambahkan bahwa mentor selalu menjawab pertanyaan baik saat kursus berlangsung ataupun setelah kursus selesai.

Sementara itu menurut Informan 3, bila mentor tidak bisa menjawab peprtanyaan pasti peserta akan menjadi ragu dan bisa membuat mereka jadi malas mengikuti kursus. Menurut Informan 5, akan ada masalah bila mentor tidak bisa menjawab pertanyaan terkait kursus kopi, karena dalam kursus itu, 
hanya mentor yang paling tahu tentang materi kursus. Dalam realitanya, mentor selalu bisa menjawab semua pertanyaan yang diajukan dengan baik, dan tidak pernah mengelak ataupun mengalihkan pembicaraan dengan peserta. Teknik itu memang tidak disarankan dan sebisa mungkin harus dihindari karena bisa menimbulkan hilangnya kepercayaan peserta kepada mentor. Kredibilitas mentor bisa hilang bila tidak bisa menjawab pertanyaan peserta, karena mentor adalah panutan para peserta kurus.

\section{KESIMPULAN}

Teknik yang dominan digunakan di dalam kursus Fulcaff untuk menjadi barista adalah teknik integrasi. Mentor berbaur dengan peserta kursus. Penggunaan teknik ini juga paling banyak dibandingkan dengan teknik yang lain. Teknik ini membantu untuk mengurangi gap antara mentor dan peserta. Teknik asosiasi melalui analogi dapat membantu peserta untuk mudah memahami istilah yang rumit. Penggunaan teknik tataan mampu merubah materi yang rumit menjadi lebih sederhana sekaligus mudah dipahami oleh peserta kursus. Teknik ganjaran mampu mendorong peserta untuk lebih semangat mencapai tujuan yang ditetapkan mentor atau tujuan dari kursus tersebut.

Terlepas dari hal keempat teknik tersebut ada satu teknik yang tidak digunakan yakni teknik redherring. Dapat disimpulkan, teknik yang paling banyak digunakan secara urut adalah teknik integrasi karena menyangkut kedekatan antara peserta dan mentor, selanjutnya adalah teknik asosiasi yang dapat membantu memudahkan peserta memahami berbagai istilah yang kurang umum. Teknik tataan yang memiliki fungsi yang kurang lebih serupa memudahkan peserta memahami melalui penyampaian yang sederhana. Keempat, teknik ganjaran yang dapat mendorong minat peserta.

Penggunaan teknik secara tepat dapat membantu menjaga minat belajar masing-masing peserta. Dengan melakukan teknik komunikasi persuasif dengan baik mentor secara langsung membantu menjaga minat belajar peserta yang sejatinya, sudah ada disaat mereka memutuskan untuk mengikuti kursus tersebut. Berdasarkan penelitian yang sudah dilakukan oleh peneliti terbukti bahwa di dalam kursus kopi yang dilakukan di kursus barista Fulcaff, sudah menggunakan teknik komunikasi persuasif secara baik sehingga dapat membantu menjaga minat belajar pesertanya.

\section{REFERENSI}

Dainton, M., \& Zelley, E. D. (2017). Applying Communication Theory for Professional Life: A Practical Introduction. SAGE Publications.

Djamarah, S. B. (2008). Psikologi Belajar. Jakarta: PT. Rineka Cipta.

Effendy, O. U. (2008). Dinamika Komunikasi. Bandung: PT. Remaja Rosdakarya.

Gumulya, D., \& Helmi, I. S. (2017). Kajian Budaya Minum Kopi Indonesia. Jurnal Dimensi Seni Rupa dan Desain, 13(2), 153-172.

Herlyana, E. (2014). Fenomena Coffee Shop Sebagai Gejala Gaya Hidup Baru Kaum Muda. Thaqafiyyat: Jurnal Bahasa, Peradaban dan Informasi Islam, 13(1), 187-204.

Littlejohn, S. W., Foss, K. A., \& Oetzel, J.G. (Eds.). (2017). Theories of Human Communication. Illinois: Waveland Press, Inc.

Mukhtar. (2013). Metode Praktis Penelitian Deskriptif Kualitatif. Jakarta: GP. Press Group.

Perloff, R. M. (2017). The Dynamics of Persuasion: Communication and Attitudes in the Twenty-First Century, New York: Routledge.

Slameto. (2010). Belajar dan Faktor-Faktor yang Mempengaruhinya. Jakarta: PT. Rineka Cipta.

Soemirat, Soleh \& Suryana, Asep. (2014). Komunikasi Persuasif. Banten: Universitas Terbuka.

Suyono, (2011) Belajar dan Pembelajaran. Bandung: PT. Remaja Rosdakarya.

Yusuf, P. M. (2010). Komunikasi Instruksional. Jakarta: Bumi Aksara. 